\title{
Exploration and Selection of White Rot Fungi as Fiber Decomposer in Feed
}

\section{${ }^{1}$ Jamila Mustabi, ${ }^{2}$ Tutik Kuswinanti, ${ }^{1}$ Laily Agustina, and ${ }^{1}$ Dan Rinduwati}

${ }^{1}$ Lecturer at the Faculty of Animal Husbandry, Hasanuddin University,

2) Faculty of Agriculture Teaching Staff, Department of Plant Pests and Diseases, Hasanuddin University, Jl. PerintisKemerdekaan Km.10 Makassar, South Sulawesi, Indonesia

Correspondence Author: Jamila Mustabi, 1Lecturer at the Faculty of Animal Husbandry, Hasanuddin University

Received date: 19 May 2018, Accepted date: 15 August 2018, Online, Online date: 20 August 2018

Copyright: (C) 2018 Jamila Mustabi et al., This is an open-access article distributed under the terms of the Creative Commons Attribution License, which permits unrestricted use, distribution, and reproduction in any medium, provided the original author and source are credited.

\begin{abstract}
The purpose of this research is to explore, isolate and then do the selection to obtain the maximum agent in degrading lignin so as to optimize the utilization of white fungus as fiber decomposers, can improve the availability and quality of feed material from waste as feed for the development of sustainable livestock. The method used is the exploration, isolation, purification and selection of lignolytic fungi. The results obtained from the exploration in Soppeng, Bulukumba and Makassar districts were 23 isolates, 15 isolates of white fungus mushrooms were purified on PDA media, and only 5 white mushroom fungi isolates grew well in the wood powder medium to obtain the fruit body, then identified macroscopic based on morphological features of basidiocarp shape, color and microscopic identification. The conclusion of this research is that there are five isolates of white fungus (Coprinus comatus, Corilopsispolyzene, Lentinustorulosus, Pleurotusostreatus and Trametes versicolor) selected, which produce the best growth diameter on PDA media and the fastest to meet the spray media bottle of wood powder.
\end{abstract}

Key words: Exploration, Selection, Isolate and White Rot Fungi

\section{INTRODUCTION}

In Indonesia, the development of livestock business often has problems in the availability of feed ingredients, especially in the dry season, because it requires knowledge in processing agro-industrial waste to be used as a feed material that can meet the nutritional needs of livestock when the availability of forage is reduced.

Agricultural and agro-industrial waste has considerable potential as a source of ruminant animal feed [1,2]. The use of agricultural industry byproducts as a cheap and easily available local food ingredient is the best strategy to reduce feed costs, because around 60-70\% of all production costs are used to supply feed. Various studies have been conducted to utilize waste that is not valuable to be a feed ingredient whose biological value is high and provides added value.

Utilization of waste as food is generally limited by several factors including low nutritional quality due to high fiber content and the presence of tissues in feed derived from waste has undergone a process of lignification (hardening). Lignin and cellulose often form lignosellulose compounds in plant cell walls which are a strong bond [3]. The older the plant, the higher the lignin level as a result the digestibility decreases with increasing lignification. Besides binding cellulose and hemicellulose, lignin also binds to cell wall proteins. The lignification and silification together affect the low digestibility, so processing needs to be done to eliminate or break the bonds that occur between the fiber components. There are several methods that can be done to increase the potential digestibility of crude fiber [4]. Increasing the quantity of parts that can be digested in low quality feed can be done through chemical, physical and biological processes. Physical treatment includes cutting, grinding, pelleting, demolition and others. The digestibility of agricultural wastes can be increased through chemical processes [4,5] as with the addition of alkalis and acids, chemical treatments that have been studied include the treatment of $\mathrm{NaOH}, \mathrm{KOH}, \mathrm{Ca}(\mathrm{OH})$ and urea. Biological treatment using biological agents or carried out using cell wall degradation enzymes such as cellulase, hemicellulase, lignin-breaking enzymes, bacteria and lignolytic fungi. The results of [7] showed that biopriming application on soybean seeds was able to increase soybean growth and production, while [8] showed that chicken feed conversion did not show a significant effect between chickens fed garbles at various levels and probiotics.

Several groups of microorganisms are reported to be able to degrade lignin compounds, because they are able to use cellulose as a carbon source for their growth substrate, whereas the lignocellulose components that can be used by livestock are cellulose and hemicellulose. The problem that often arises in the processing of lignocellulosic materials using microorganisms is the loss of the organic matter of the substrate used by microorganisms as a source of nutrients in the bioconversion process.[9] stated that ideal microorganisms in bioconversion of lignocellulose into animal feed are microorganisms that have great ability in decomposing lignin but low in degradation of cellulose and hemicellulose. Some lignolytic fungi do not have the ability to use lignin as a single source for energy and carbon and depend on polysaccharides which are easily digested in the substrate.

Some groups of white rot fungi are reported to be able to degrade lignin compounds, generally white rot fungi are divided into three groups [9], namely: 1) fungi that break down cellulose and hemicellulose first then lignin, 2) metabolize lignin more first then cellulose and hemicellulose and 3) are able to degrade all cell wall polymers simultaneously. Based on the consideration that white rot fungi are the most active lignin degrading, it is important to conduct research that begins with the exploration process, isolates and then is selected so that a maximum agent can be obtained to degrade lignin so as to optimize the use of white rot fungi as fiber decomposers, improve availability and the quality of feed ingredients from waste as feed for sustainable livestock 


\section{Exploration:}

\section{RESEARCH MATERIALS AND METHODS:}

The exploration of white rot fungi begins with taking mushrooms that grow in weathered wood around Makassar City, Bulukumba and Soppeng district, South Sulawesi Province in Indonesia. Site selection is based on plants that dominate the area. Soppeng Regency is an area that is overgrown with agricultural crops, Bulukumba Regency is an area that is overgrown with plantations and in Makassar City industrial centers such as sawmills. White rot fungi found macroscopically recorded morphologically and taken pictures. Furthermore, mushrooms are collected using paper bags and taken to the laboratory to be isolated and coded.

\section{Isolation:}

The isolation method used refers to [10], the scissors are cleaned with $70 \%$ alcohol, then a portion of the mushroom himenium (where basidiospora is formed), is cut into small pieces. The pieces are dipped in sterile distillation aqua, then dipped in $70 \%$ alcohol, then dipped back into sterile distillation aqua, then placed on sterile filter paper in an oven-treated petri dish, then incubated at $30 \mathrm{oC}$, for $2-3$ days. Growing fungus colonies were taken with tweezers and transferred to a petri dish containing Potato Dextro Agar (PDA) medium.

\section{Purification:}

Purification is done by taking isolates from petri dishes containing a single colony of fungi that have grown. The treatment was repeated several times until the pure mycelium was obtained. The culture was then incubated at room temperature for 48 hours. Pure isolates are reproduced by growing isolates on several PDA media. In pure mushroom isolates measurements of growth diameter were carried out on the $3 \mathrm{rd}$, 5 th and 7 th days after planting. This measurement aims to select the fastest growing fungal isolates in petri dishes.

Lignolytic Mushroom Selection:

At this stage purified mushroom isolates on PDA media, cut with temporary cork ( $7 \mathrm{~mm}$ diameter) and inoculated into media using $92 \%$ wood powder, $6 \%$ rice bran and $2 \% \mathrm{CaCO} 3$, and added water to $70 \%$ moisture content then mixed until homogeneous [11]. Each observation bottle $(9 \mathrm{~cm}$ high and $5 \mathrm{~cm}$ diameter) was filled with 50 grams of media, then closed tightly and sterilized into an autoclave at $121^{\circ} \mathrm{C}$ and 1.1 atmospheric pressure for $20-30$ minutes for 2 days until all the spores and microbes were really dead right. Inoculation is done the next day when the media is cold. 5 pieces of agar and mycelia from the $10 \mathrm{~mm}$ x $10 \mathrm{~mm}$ petri dish were needed for each observation bottle, after which they were mixed by stirring. The bottle was then closed and incubated at $30-32^{\circ} \mathrm{C}$, then the selection was done to find the five fastest growing fungal isolates and the fastest mycelium isolates filled the observation bottle.

Five selected fungal isolates were grown on wood powder media for 10, 20 and 30 days and then [12] analyzed to determine the levels of lignin, cellulose and hemicellulose in each bottle of observation, first determined the levels of wood powder ADF and NDF. Measurement data were analyzed descriptively.

\section{RESULTS AND DISSCUSSION:}

From exploration in several locations in Kab. Soppeng, Bulukumba and Makassar, found various types of white rot fungi, but only 23 isolates were successfully grown on filter paper. The isolates were coded according to where they were found, BLK codes were found in Bulukumba Regency; SPNG from Soppeng and MKS districts was found in Makassar. The 23 fungal isolates were isolated and purified on PDA media, then observed the growth diameter of the petri dish, then ranked to get the best 15 isolates. The results of the measurement of the 23 fungal isolates on PDA media can be seen in Table 1 .

Table 1: Results of measurements of growth diameter and ranking on all 23 white rot fungi isolates on days 3,5 and 7 days on PDA media.

\begin{tabular}{|c|c|c|c|c|c|}
\hline \multirow[t]{2}{*}{ Isolates } & \multicolumn{3}{|c|}{ Measurement Diameter (cm) Days to - } & \multirow[t]{2}{*}{ Average } & \multirow[t]{2}{*}{ Rank } \\
\hline & 3 & 5 & 7 & & \\
\hline $1 \mathrm{BLK}$ & 7.5 & 9 & 9 & 8.50 & 1 \\
\hline $2 \mathrm{BLK}$ & 5.2 & 9 & 9 & 7.73 & 2 \\
\hline $3 \mathrm{BLK}$ & 6.1 & 6.5 & 6.8 & 6.47 & 7 \\
\hline $5 \mathrm{BLK}$ & 5.2 & 7.3 & 7.3 & 6.60 & 6 \\
\hline $6 \mathrm{BLK}$ & 3 & 5.1 & 5.8 & 4.63 & 13 \\
\hline $8 \mathrm{BLK}$ & 4.2 & 5.2 & 5.8 & 5.07 & 11 \\
\hline C MKS & 5.4 & 7.6 & 9 & 7.33 & 3 \\
\hline SPNG & 2.5 & 5.3 & 9 & 5.60 & 10 \\
\hline $1 \mathrm{MKS}$ & 3.3 & 9 & 9 & 7.10 & 4 \\
\hline $3 \mathrm{MKS}$ & 4.5 & 7.3 & 9 & 6.93 & 5 \\
\hline 5 MKS & 0.4 & 3.3 & 9 & 4.23 & 14 \\
\hline 6 MKS & 0.3 & 3.5 & 6.2 & 3.33 & 18 \\
\hline $7 \mathrm{MKS}$ & 0.3 & 5.7 & 6 & 4.00 & 15 \\
\hline $8 \mathrm{MKS}$ & 0.6 & 3.5 & 7.9 & 4.00 & 16 \\
\hline $10 \mathrm{MKS}$ & 1.2 & 2.3 & 7.8 & 3.77 & 17 \\
\hline $11 \mathrm{MKS}$ & 0.8 & 1.4 & 3.3 & 1.83 & 22 \\
\hline $14 \mathrm{MKS}$ & 0.2 & 2.2 & 4.2 & 2.20 & 21 \\
\hline 15 MKS & 0.2 & 1.2 & 1.9 & 1.10 & 23 \\
\hline 16 MKS & 0.1 & 3.5 & 5.1 & 2.90 & 19 \\
\hline $17 \mathrm{MKS}$ & 1.3 & 2.5 & 3.4 & 2.40 & 20 \\
\hline 18 MKS & 1 & 5.7 & 7.3 & 4.67 & 12 \\
\hline
\end{tabular}


Citation: Jamila Mustabi et al., 2018. Exploration and Selection of White Rot Fungi as Fiber Decomposer in Feed. Advances in Environmental Biology., 12(8): 16. DOI: $10.22587 / \mathrm{aeb} .2018 .12 .8 .1$

\begin{tabular}{|l|l|l|l|l|l|}
\hline $19 \mathrm{MKS}$ & 3 & 6.1 & 8.4 & 5.83 & 8 \\
\hline $20 \mathrm{MKS}$ & 2.8 & 5.4 & 9 & 5.73 & 9 \\
\hline
\end{tabular}

Information: BLK = Bulukumba MKS = Makassar SPNG = Soppeng Ranking = Based on the highest average

The 15 isolates which were selected were then grown in wood powder media and the growth of fungal mycelium was observed, to select the five isolates which were the fastest growing in meeting the observation bottle after inoculation. The results of measurements of 15 white rot fungi isolates in wood powder media can be seen in Table 2 .

Table 2: Observation results of growth and ranking in all 15 white rot fungi isolates on wood media.

\begin{tabular}{|c|c|c|c|c|}
\hline Isolates & Growth day to .. & $\begin{array}{c}\text { Meet } \\
\text { Spawn day.. }\end{array}$ & Unit & Rank \\
\hline $1 \mathrm{BLK}$ & 17 & 43 & & 3 \\
\hline 2 BLK & 14 & 38 & & 2 \\
\hline $3 \mathrm{BLK}$ & 34 & - & & 9 \\
\hline $5 \mathrm{BLK}$ & 69 & - & & 13 \\
\hline C MKS & 45 & 90 & $1 / 2$ bottle & 8 \\
\hline SPNG & 21 & 73 & & 4 \\
\hline $1 \mathrm{MKS}$ & 10 & 25 & & 1 \\
\hline $3 \mathrm{MKS}$ & 23 & 90 & & 5 \\
\hline $5 \mathrm{MKS}$ & 37 & - & & 10 \\
\hline $6 \mathrm{MKS}$ & 72 & - & & 14 \\
\hline 8 MKS & 67 & 82 & & 6 \\
\hline $10 \mathrm{MKS}$ & 78 & - & & 15 \\
\hline $18 \mathrm{MKS}$ & 62 & - & & 12 \\
\hline 19 MKS & 42 & - & & 11 \\
\hline $20 \mathrm{MKS}$ & 23 & 90 & $1 / 2$ bottle & 7 \\
\hline
\end{tabular}

Information: BLK = Bulukumba; MKS = Makassar; SPNG = Soppeng; Ranking = Based on the speed of growth in fulfilling the spawn (bottle of seed)

The results of observations in Table 2. obtained five white rot fungi isolates that are the best and fastest growing spawn bottles. The five fungal isolates were grown on wood powder media until they obtained the fruit body, then macroscopic identification was carried out based on morphological characteristics namely basidiocarp shape and color and microscopic identification. One isolate from Bulukumba was identified in more detail using 3 specific primers which amplified ribosome and ITS regions, then disequensing. Four isolates that were identified microscopically and macroscopically were 1 BLK isolate (Coprinus comatus), SPNG isolate (Pleurotusostreatus), $1 \mathrm{MKS}$ isolate (Lentinustorulosus) and $3 \mathrm{MKS}$ isolates (Trametes versicolor). Each isolate has morphological characteristics that are different from one another.

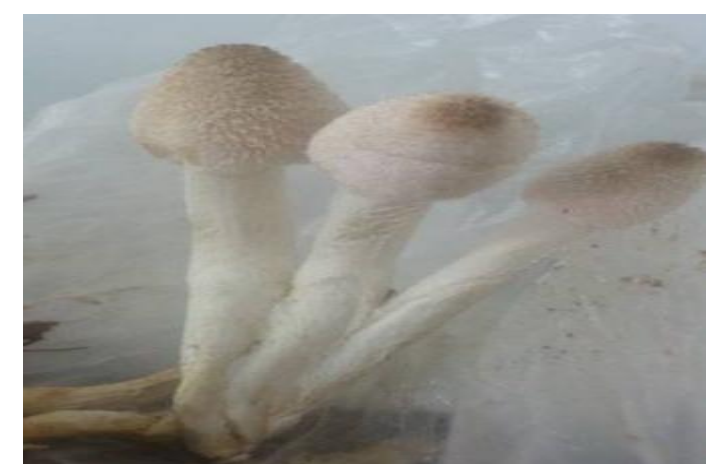

Fig. 1: Fruit body 1 BLK isolate (Bulukumba) in organic media, 50 days after incubation.

The body shape of the mushroom fruit is generally composed of parts called the hood (pileus), blades (lamellae), rings (annulus), stems (stipe), cup (volva), and false roots (rhizoids). C.comatus mushroom isolates (Figure 1.) have a common name: maneshaggy; Pileus: cap 5-14cm high, with an area of $2.5-4.5 \mathrm{~cm}$, columnar, bell-shaped, dry surface, white with a centerpiece of chocolate, bent scales, flesh thin, white, and soft; lamellae have a rather liquid boundary, blackish;

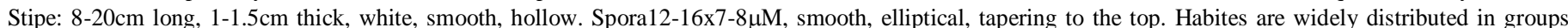
often found in moist, grassy soils, on wood chips, litter, straw, and organic matter, mostly grown after the rainy season [13]. This isolate can be consumed and has a delicious taste when young. C.comatus is one of the easy to identify Basidiomycetes groups. According to [14] capC.comatus measuring 3-15 $\mathrm{cm}$, oval or roundcylindrical when young, at an age that has not produced black "ink", dry, whitish with a brown center, but if it has formed "ink", the color is very patterned. Stem: 5-20 cm thick, 1-2 cm thick, smooth, white, easily separated from the hat, hollow, white flesh all over; soft. Smell and taste: Not typical.

Pleurotusostreatus(Figure 2), P. ostreatus or oyster mushrooms. Oyster mushrooms can be used for industrial purposes in corememediation. Oyster mushrooms can be considered as a medicinal mushroom, because they contain the fatty acids as long as they work to reduce cholesterol. normal size: $5-15 \mathrm{~cm}$, cap type, shaped channel, stem type: lateral, basic or non-existent, colored spores: white, cream or yellow, habitat: Grows on wood, meat-brown or blue-gray, 10-20 $\mathrm{cm}$ stem. Oyster mushrooms can kill nematodes and bacteria with immunity, Cap: 4-15 cm, convex, flat, fan-shaped, rather oily When young and fresh, smooth, 
pale brown to dark brown. [15,16,17] stated that, P. ostreatus had Pileus: broad cap5-25cm, Stipe: often not found, but when it was present, short and thick: 0.5 $3.0 \mathrm{~cm}, 0.5-2.0 \mathrm{~cm}$, spore7, 5-9x3,5-4,5mM, smooth, elliptical. Habitat of solid and hard wood is often consumed during the summer, although some people are allergic to consuming this fungus.

Lentinustorulosus (Figure 3.) Scientific name: Lentinustorulosus(Release.) Lloyd, Phylum: Basidiomycota, Order: Polyporales, Family: Polyporaceae. Dimensions: width caps $3-13 \mathrm{~cm}$, length stipe $1-4 \mathrm{~cm}$ and thickness $5-25 \mathrm{~mm}$. Lentinus mushroom belongs to the class of Basidiomycetes, the order of Polyporales with the Lentinaceae family which has a macroscopic fruit body with a clay structure and is sturdy and durable [18]. In general, this fungus has the following characteristics: shaped like an umbrella; medium size; diverse colors; the surface of the hood (pileus) is smooth, hairy or scaly with the center part being depressed, notched in (umbilicate); stalks are generally not centered or eccentric, sometimes forming several branches so that they look like bunches; the lamela is close and down reaches the decurrent; spores are white [19]. Some types of Lentinus can produce active compounds that can inhibit disease pathogens (antimicrobial, antibacterial, antifungal) and efficacious as anticholinesterol and antihypertensive as well as being food.

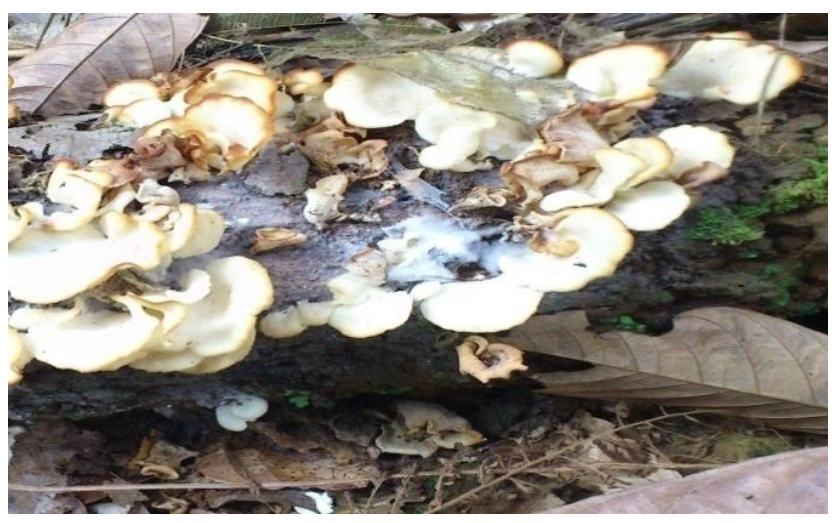

Fig. 2: SPNG isolate (Pleurotusostreatus) found in Soppeng.

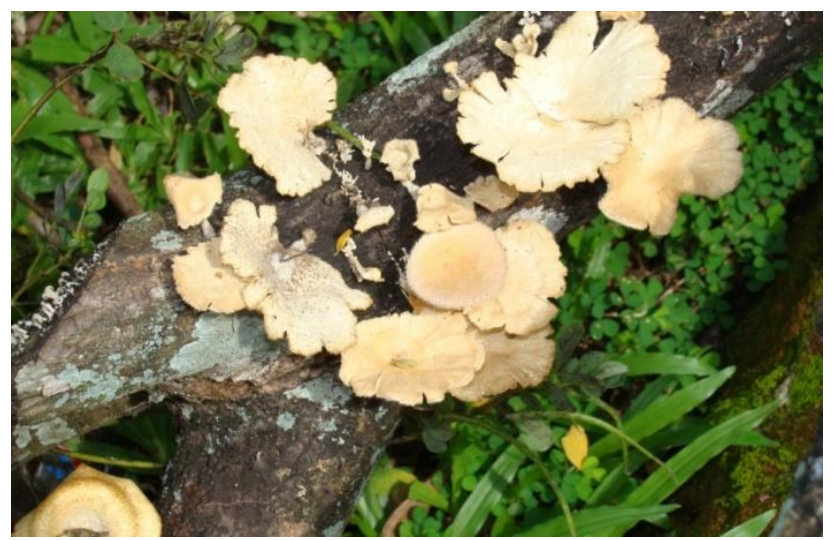

Fig. 3: Isolate 1 MKS (Lentinustorulosus) from Makassar.

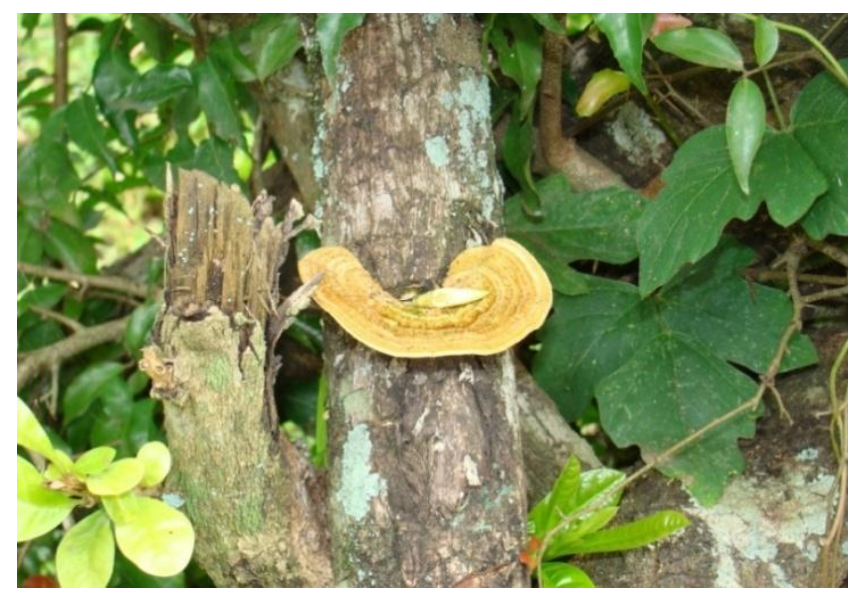

Fig. 4: Isolate 3 MKS (Trametes versicolor).

Trametes versicolor (Fig. 4), often called "turkey tail," T. versicolor is one of the most common fungi in the forests of North America, found almost everywhere there is a dead and rotten wood log. The colors of hats that are very varied, but tend to brown and reddish brown. Smooth surface cap like velvet and porous. Fan-shaped, plugged in one side or only near the middle of one side, with colorful zones. T. versicolor has thin flesh, usually less than $2 \mathrm{~mm}$ and fibrous. Spores 4-6x1,5-2,5mM, slightly curved-cylindrical. Habitats are usually on logs from hard wood, edible but too hard to try [20,13,21].

The 2 BLK isolates (Figure 5.) were analyzed in more detail using 3 types of primers namely NS1 and NS4 (for SSU 18S RNA), LROR and LR5 (for LSU 28S RNA) and ITS4, showing amplification with a band measuring 4000-5000 bp (Figure 6). 
In Figure 6. it can be seen that the PCR amplification results using the ITS primer, resulting in a weak band compared to the other two primers that amplified the SSU and LSU regions, this is thought to be due to the lack of DNA template concentration used. At the next stage DNA sequencing is carried out which is a process or technique for determining the sequence of basanucleotides in a DNA molecule. DNA sequencing can be used to determine the identity and function of genes or other DNA fragments by comparing the sequence with other known DNA sequences (Bieber, 2004). The results of dendogram analysis using primers amplifying the area of 18S RNA can be seen in Figure 7.

The results of sequencing showed that 2 BLK isolates were C. polyzona[22]. According to the American mycology, the Polyporaceae is a group of fungi in the Basidiomycota Division. According to [23], the flesh of the fruit body varies from soft to clay. Some members of this group have hymenium in the lower pores of the cap, but some have gills or structures that resemble gills. Most of these mushrooms have white spore powder but some have colorful spores. The growth of five white rot fungi isolates in the field, petri dishes, baglog and comparison of images from literature can be seen in Figure 8 .

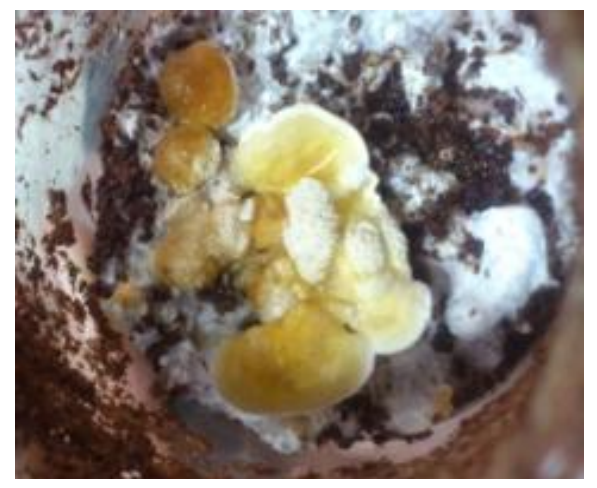

Fig. 5: Fruit body of Isolate 2 BLK (Bulukumba) in baglog after incubation for 80 days

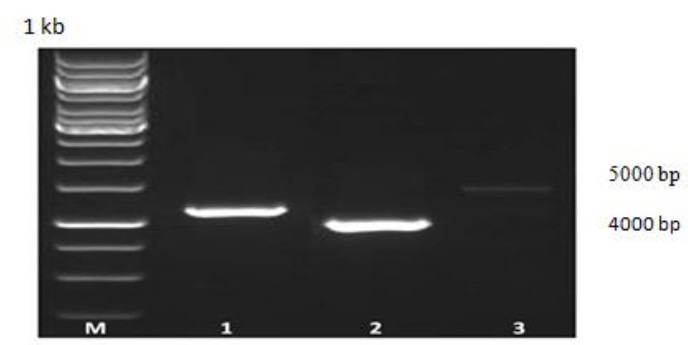

Fig. 6: Results of PCR DNA amplification of 2 BLK isolates using SSU primers (1), LSU primers (2) and ITS primers (3).

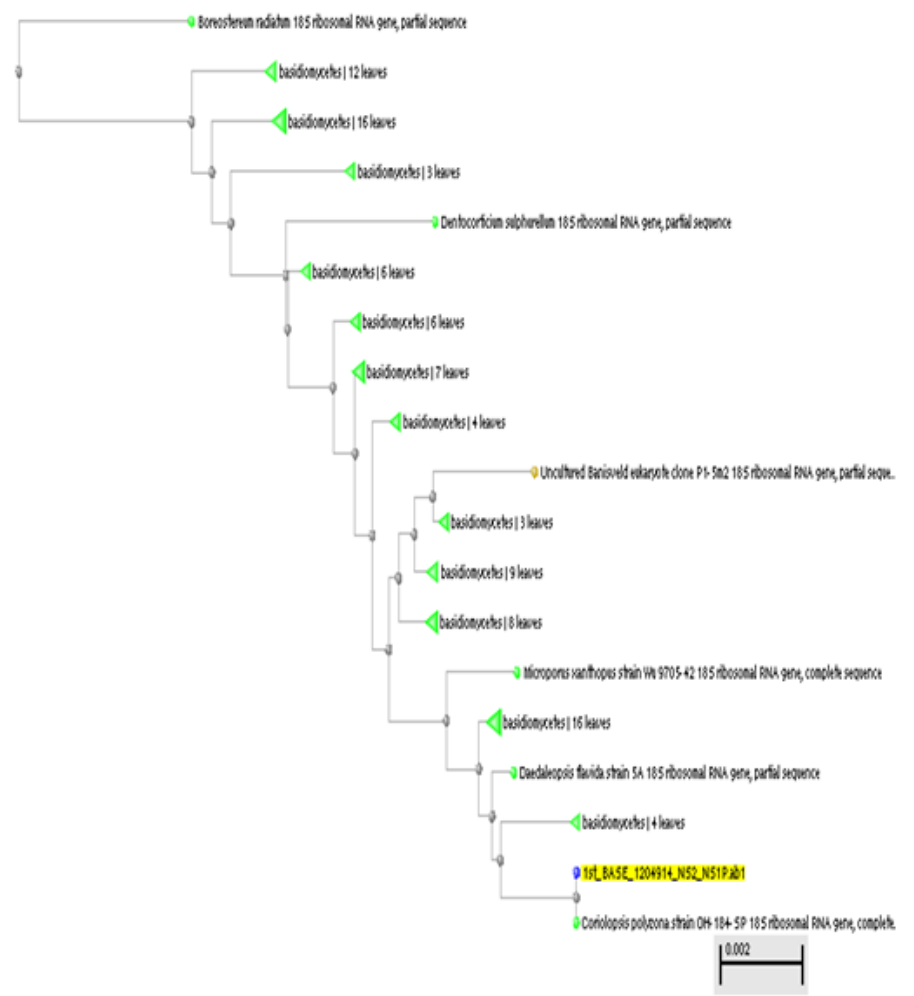

Fig. 7: The results of dendogram analysis using NS4 primer amplifying the SSU area 18 S RNA placed 2BLK isolates in the same group as C. polyzona. 


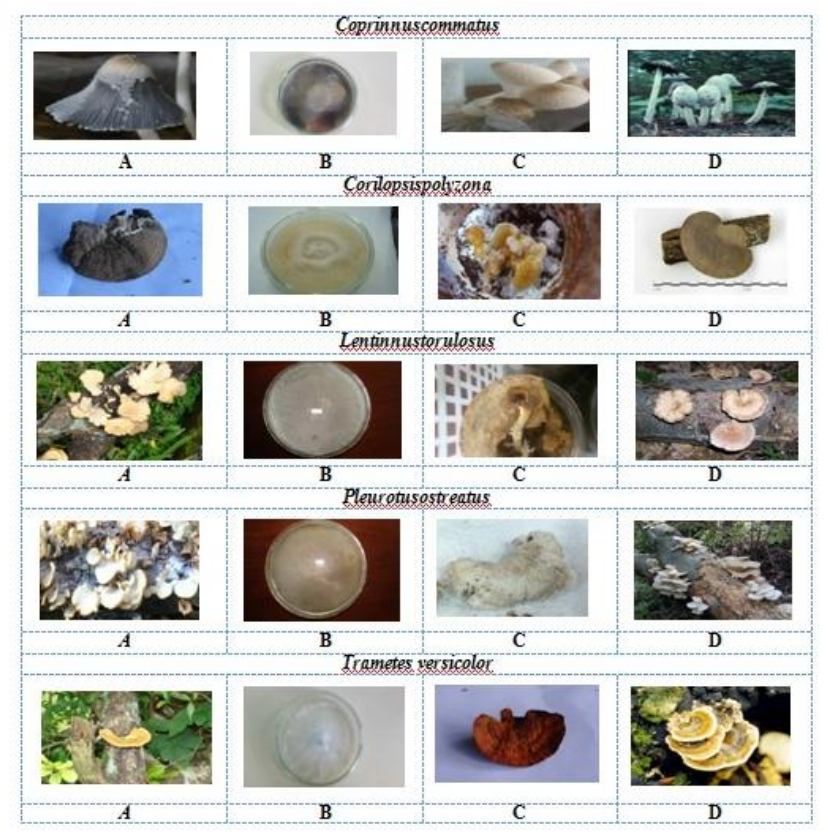

Fig. 8: Growth of five isolates in (A) the field, (B) petri dishes, (C) baglog and (D) comparison of images from literature.

\section{CONCLUSION:}

There were five white rot fungi isolates (Coprinus comatus, Corilopsispolyzona, Lentinustorulosus, Pleurotusostreatus and Trametes versicolor), which resulted in the best growth diameter on PDA media and the fastest filled bottle of wood powder media.

\section{REFERENCES}

[1] Mariyono dan, E., Romjali, 2007. PetunjukTeknisTeknologiInovasiPakanMurahuntuk Usaha Pembibitan SapiPotong. Pusat Penelitian dan PengembanganPeternakan. Badan Penelitian dan Pengembangan Pertanian. Departemen Pertanian.

[2] Soejono, M.R.Utomo dan Widyantoro. 1987. Peningkatan Nilai Nutrisi Jerami Padidengan Berbagai Perlakuan. Proceeding Bioconversion Project Second Workshop on Crop Residues for Feed and Other Purposes, Grati.

[3] Sutardi, T., 1980. LandasanIlmuNutrisiDepartemenIlmuMakananTernak, FakultasPeternakanInstitutPertanian Bogor.

[4] Preston, T.R. and R.A. Leng, 1987. Matching Ruminant Production System with Available Resources in The Tropics and Subtropics. Penambul Books Armidale, Australia.

[5] Noor, N.A.M., M.I.N. Isa, 2015. Structural and conduction studies of solid biopolymer electrolytes system based on carboxymethyl cellulose. American-Eurasian Journal of Sustainable Agriculture, 15-23.

[6] Rozali, M.L.H., N.H. Ahmad, M.I.N. Isa, 2015. Effect of adipic acid composition on structural and conductivity solid biopolymer electrolytes based on carboxy methylcellulose studies. American-Eurasian Journal of Sustainable Agriculture, 39-46.

[7] Suarni, Y., A. Bahrun, G.A.K. Sutariati, 2016. Effectivity of biopriming pre-planting seed based mixed indigenous rhizobakteria to improve plant growth and yield of soybean. Advances in Environmental Biology, 10(4), 6-14.

[8] Bidarnamani, E., M.S. Shargh, B. Dastar, S. Zerhdaran, 2015. Effect of Different Levels of AgaricusBisporus Mushroom Waste with and without Prebiotic on Meat Quality of Broiler Chickens. Advances in Environmental Biology, 9(4): 421-427.

[9] Murni, R., Suparjo, Akmal, dan B.L. Ginting, 2008. Buku Ajar TeknologiPemanfaatanLimbahuntukPakan. LaboratoriumMakananTernak. FakultasPeternakanuniversitas Jambi.

[10] Chang, S.T., 1982. Mushroom Spawn. Dalam: Chan, S.T. and T.H. Quimio. Tropical Mushrooms: Biological Nature and Cultivation Methodes. The Chinese University Press. Hongkong.

[11] Achmad, Mugiono, T. Arlianti dan C. Azmi, 2011. Panduan LengkapJamur. Jakarta: PenebarSwadaya.

[12] Van Soest P.J., 1976. New Chemical Methods for Analysis of Forages for The Purpose of Predicting Nutritive Value. Pref IX International Grassland Cong.

[13] Bougher, N.L. and K. Syme, 1998. Fungi of Southern Australia. University of Western Australia Press: Nedlands, Australia. 391

[14] Orton, P.D., R. Watling, 1979. British Fungus Flora: Agarics and Boleti. Vol 2. Coprinaceae: Coprinus. Royal Botanic Garden: Edinburgh, Scotland. $149 \mathrm{p}$

[15] Petersen, R.H. and I. Krisai-Greilhuber, 1996. An epitype specimen for Pleurotusostreatus. Mycol. Res. 100(2): 229-235.

[16] Bas, C., T.W. Kyper, M.E. Noordeloos, E.C. Vellinga, 1990. Flora AgaricinaNeerlandica-Critical monographs on the families of agarics and boleti occuring in the Netherlands. Volume 2. Pluteaceae, Tricholomataceae. A. A. Balkema: Rotterdam, Netherlands.

[17] Watling, R. and N.M. Gregory, 1989. British Fungus Flora: Agarics and Boleti, 6. Crepidotaceae and other pleurotoid agarics. Royal Botanic Garden: Edinburgh, Scotland.

[18] Sudirman, L.I., 1995. DeteksiSenyawaAntimikroba yang DiisolasidariBeberapaLentinusTropisdenganMetodeBioautografi. Hayati, Juni 2005. Hlm 67-72. ISSN 0854-8587.

[19] Pegler, D. and T.W.K.Young, 1983. Anotomy of The Lentinus hymenophore. Trans. Br. Soc., 80(3): $469-482$.

[20] Bernicchia, A., 2005.Polyporaceaes.1. (Fungi Europaei). EdizioniCandusso: Alassio, Italy, 807.

[21] Gilbertson, R.L. and L. Ryvarden, 1987. North American Polypores, vol. 2. Fungiflora: Oslo, Norway.

[22] Ryvarden, L., I. Johansen, 1980. A preliminary polypore flora of East Africa. Synopsis Fungorum. Oslo, Norway: Fungiflora, 282.

[23] Corda, A.C.J. 1839. Iconesfungorumhucusquecognitorum, 1-55. 